\title{
INOVASI STRATEGI PEMBELAJARAN INKUIRI DALAM PEMBELAJARAN
}

\author{
Risqyanto Hasan Hamdani* \& Syaiful Islam** \\ Universitas Nurul Jadid \\ *risqyantohasan@gmail.com \\ **syaifulislam182@gmail.com
}

\begin{abstract}
This research is motivated by assumption that in maximizing student learning result it is deemed necessary to present new inovation in a learning process. This study was purposed to fully describe the role of inquiry learning strategies that have collaborated with other learning strategies or methods in maximizing learning result obtained by students of SMKN 02 KRAKSAAN. The implementation of strategies or learning methods is considered to be dominantly influential in improving student learning result. This research method uses descriptive research methods that are collaborative in qualitative form. The subject of this research are the teachers and students of SMKN 02 KRAKSAAN. Research data obtained from interviews, observations, and documentation. The result of this study showed an increase in the average student learning result by 15 points (documentation result) from the previous action (the implementation of inquiry learning strategies). Things that show the enormity of the influence given by inquiry learning strategies in maximizing student learning result.
\end{abstract}

Keywords : Inquiry Learning, Learning Result

\begin{abstract}
Abstrak : Latar belakang penelitian ini berangkat dari asumsi bahwa dalam memaksimalkan hasil belajar siswa dipandang perlu untuk menghadirkan inovasiinovasi baru didalam suatu proses pembelajaran. Penelitian ini bertujuan untuk mendeskripsikan secara penuh peran dari strategi pembelajaran inkuiri yang telah dikolaborasikan dengan strategi atau metode pembelajaran yang lain dalam memaksimalkan hasil belajar yang di dapat oleh siswa di SMKN 02 Kraksaan, penggunaan strategi atau metode pembelajaran dianggap berpengaruh secara dominan dalam meningkatkan hasil belajar siswa. Metode penelitian ini menggunakan metode penelitian deskriptif yang bersifat kolaboratif dengan bentuk kualitatif. Subjek penelitian ini adalah guru dan siswa SMKN 02 Kraksaan. Data penelitian diperoleh dari wawancara, observasi, dan dokumentasi. Wawancara digunakan untuk menelusuri dan mengenal lebih jauh terhadap objek penelitian, observasi digunakan untuk mengetahui rangkaian aktivitas anak dalam proses pembelajaran dan untuk mengetahui aktivitas guru selama proses belajar mengajar, sedangkan dokumentasi digunakan untuk memperkuat bukti hasil temuan-temuan dari wawancara dan observasi. Hasil dari penelitian ini menunjukkan peningkatan rata-rata hasil belajar siswa sebesar 15 poin dari sebelum melakukan tindakan
\end{abstract}


(penerapan strategi pembelajaran inkuiri). Hal ini menunjukkan besarnya pengaruh yang diberikan strategi pembelajaran inkuiri dalam memaksimalkan hasil belajar siswa.

Kata Kunci : strategi pembelajaran inkuiri, Hasil Pembelajaran

\section{PENDAHULUAN}

Dalam berkembangnya zaman, pendidikan selalu mendapatkan afeksi dari setiap ilmuan-ilmuan. Perdebatan mengenai pendidikan seakan-akan tak pernah surut. Dalam keadaan apapun pendidikan tetap selalu diperdebatkan baik dalam keadaan berkembang, maju, stagnan atau bahkan dalam keadaan tenggelam sekalipun ${ }^{1}$.Perdebatan tersebut tak lain bertujuan untuk menemukan langkah-langkah dan inovasi-inovasi baru untuk meningkatkan derajat pendidikan menjadi lebih baik lagi. Berbagai macam cara telah dilakukan oleh pemerintah untuk meningkatkan kualitas pendidikan yang ada di Indonesia, salah satunya dengan mengembangkan kurikulum yang ada serta adanya usaha peningkatan kualitas tenaga pengajar (pendidik/guru) melalui diklat-diklat keguruan, workshop dan seminar.

Pendidikan mempunyai fungsi yang sangat strategis untuk mencerdaskan kehidupan bangsa dan meningkatkan kualitas sumber daya manusia dalam upaya meraih cita-cita bangsa Indonesia serta menciptakan kesejahteraan umum². Lewat pendidikan bermutu, bangsa dan negara akan terjunjung tinggi martabat di mata dunia. Oleh karenanya diperlukan strategi bagaimana pendidikan bisa menjadi sarana untuk membuka portal pikir peserta didik bahwa ilmu yang mereka pelajari memiliki kebermaknaan untuk hidup sehingga ilmu tersebut mampu mengubah sikap, pengetahuan, dan keterampilan menjadi lebih baik².

Salah satu upaya yang bisa dilakukan untuk meningkatkan kualitas pendidikan yakni dengan mengembangkan kurikulum sesuai dengan kebutuhan di zamannya. Kurikulum pendidikan dikembangkan dengan dasar kesadaran bahwa ilmu

\footnotetext{
${ }^{1}$ Ahmad Tafsir, Filsafat Pendidikan Islam,(interaksi Jasmani, Rohani, Kalbu Memanusiakan Manusia), Remaja Rosda Karya, Bandung.[Google Scholar], 2006.

${ }^{2}$ Fathul Jannah, 'Pendidikan Islam Dalam Sistem Pendidikan Nasional', Dinamika IImu, 13.2 (2013), 161-73.

${ }^{3}$ Aris Shoimin, 68 Model Pembelajaran Inovatif Dalam Kurikulum 2013 (Yogyakarta: Ar-ruzz media, 2017).
} 
pengetahuan, teknologi dan seni akan terus berkembang. Kurikulum dikembangkan dengan melihat kondisi dan kepentingan bersama serta daerah untuk membangun kehidupan bermasyarakat, berbangsa dan bernegara. Pengembangan kurikulum perlu dilakukan karena adanya provokasi zaman yang harus dihadapi, baik provokasi internal maupun eksternal.Oleh sebab itu, untuk menghadapi tuntutan perkembangan zaman dirasa perlu adanya perbaikan pola pikir dan penguatan tata kelola kurikulum pendidikanserta pendalaman dan perluasan materi. Seperti saat ini Kurikulum Tingkat Satuan Pendidikan (KTSP) tahun 2006 dikembangkan menjadi Kurikulum $2013^{4}$.

Guru yang memiliki tugas mengajar, membimbing serta pelaksana dalam implementasi kurikulum 2013 dituntut mampu menerapkan kurikulum 2013 secara tepat, yaitu proses penilaian (kogniti, afektif, psikomotorik) dan kompetensi lulusan agar mampu meningkatkan kompetensi siswa untuk menghasilkan lulusan yang mampu menghadapi tantangan global ${ }^{5}$. Pola pembelajaran kurikulum 2013 bersifatstudent centered. Jadi, gurudapat memberikan inovasi-inovasi dalam pembelajaran yang telah didesain dengan baik sehingga peserta didik mudah menerima materi, melalui implementasi strategi pembelajaran inkuiri pada kurikulum 2013. Hal ini ditujukan dalam rangka mempermudah peserta didik belajar, sehingga pembelajaran bisa berjalan maksimal dan tujuan pendidikan bisa terealisasi.

Penggunaan strategi pembelajaran inkuiri merupakan inisiasi dari guru SMKN 02 kraksaan. Karena strategi pembelajaran inkuiri yang sangat ideal untuk diterapkan terhadap peserta didik yang kurang aktif dalam mengikuti pembelajaran. Strategi pembelajaran semacam ini sangat dibutuhkan oleh peserta didik di zaman sekarang mengingat perkembangan teknologi yang sangat pesat mempermudah mereka untuk mengakses ilmu-ilmu atau informasi-informasi terbaru, realita yang terjadi saat ini, hal tersebut dapat mengakibatkan menurunnya semangat belajar peserta didik dikarenakan mereka beranggapan semua ilmu pengetahuan sudah terangkum rapi di dalam gadget mereka. Itu menjadi sebuah problem dan sudah

\footnotetext{
${ }^{4}$ Ruwiah Abdullah Buhungo, 'IMPLEMENTASI DAN PENGEMBANGAN KURIKULUM 2013 PADA MADRASAH ALIYAH', Jurnal Manajemen Pendidikan Islam, 3.1 (2015), 105-13.

${ }^{5}$ Murni Eva Marlina, 'Kurikulum 2013 Yang Berkarakter', Jurnal JUPIIS 2085-482X, Vol 5. No 2 (2013), 27-38.
} 
menjadi tugas guru untuk bisa merubah pola pikir mereka sehingga hal yang menjadi tujuan dalam sebuah pembelajaran bisa benar-benar terlaksana.

Keberhasilan penerapan strategi pembelajaran inkuiri ini didukung oleh penelitian terdahulu yang berjudul "Penggunaan Metode Inkuiri untuk Meningkatkan Hasil Belajar IPS Siswa di Kelas IV SDN 27 Batang Anai Kabupaten Padang Pariaman", "Peningkatan Aktivitas Dan Hasil Belajar Mata Diklat Produktif Pemasaran Dengan Menggunakan Metode Inkuiri Pada Siswa Kelas XI Pemasaran SMK Negeri 02 Purworejo Semester Genap"7, dan "Peningkatan Hasil Belajar Matematika melalui Metode Inkuiri di Kelas IV SDN 13 IV Koto Aur Malintang Kabupaten Padang Pariaman"».

Awalnya model pembelajaran ini hanya digunakan untuk mengajarkan ilmu pengetahuan alam? , namun seiring dengan berkembangnya kurikulum serta adanya inovasi-inovasi baru dalam dunia pendidikan, kini model pembelajaran inkuiri bisa diterapkan dalam semua mata pelajaran seperti ilmu pengetahuan sosial, mata pelajaran yang bersifat umum seperti matematika, hingga mata pelajaran khusus seperti pendidikan agama islam.

Kesuksesan guru dalam mengajar tentunya disebabkan dengan adanya strategi yang tepat dalam proses pembelajaran, yakni dengan menggunakan strategi pembelajaran inkuiri. Guru SMKN 02 kraksaan yakin bahwa karakter peserta didik di zaman milenial merupakan peluang besar untuk meningkatkan kompetensi peserta didik dan menanamkan sikap-sikap positif terhadap peserta didik melalui pendidikan.

\section{Metode dan Pendekatan Penelitian}

Dalam penelitian ini penulis menggunakan pendekatan kualitatif, penelitian ini termasuk dalam field research (penelitian lapangan), jenis penelitian kualitatif ini adalah studi kasus, yang mana penelitian ini menggambarkan tentang suatu gejala

\footnotetext{
${ }^{6}$ Yeni Elfida, 'Penggunaan Metode Inkuiri Untuk Meningkatkan Hasil Belajar IPS Siswa Di Kelas IV SDN 27 Batang Anai Kabupaten Padang Pariaman', 1 (2017), 55-61.

${ }^{7}$ Tri Nurwati, 'Peningkatan Aktivitas Dan Hasil Belajar Mata Diklat Produktif Pemasaran Dengan Menggunakan Metode Inkuiri Pada Siswa Kelas XI Pemasaran SMK Negeri 02 Purworejo Semester Genap Tahun 2010/2011', 2011, 193-205.

${ }^{8}$ Lely, 'Peningkatan Hasil Belajar Matematika Melalui Metode Inkuiri Di Kelas IV SDN 13 IV Koto Aur Malintang Kabupaten Padang Pariaman', 1 (2017), 23-30.

${ }^{9}$ Hamzah B Uno, Model Pembelajaran Menciptakan Proses Belajar Mengajar Yang Kreatif Dan Efektif, Jakarta: Bumi Aksara, 2009.
} 
tertentu secara rinci dan mendalam. Yang mana akan menghasilkan data deskriptif berupa ucapan, tulisan dan tingkah laku yang diamati dari subyek penelitian ${ }^{10}$. Penelitian dengan menggunakan metode kualitatif bersifat deskriptif, dimana data yang dikumpulkan lebih banyak berupa kata-kata atau gambar daripada angka-angka serta peneliti dan informan juga dapat berhubungan secara langsung ${ }^{11}$.

\section{Hasil dan Diskusi}

\section{Pengertian Strategi Pembelajaran}

Strategi dapat disebut sebagai "a plan, method, or series of well-designed activities to achieve certain educational goals" oleh karena itu, strategi pembelajaran dapat diartikan sebagai perencanaan yang berkaitan dengan rangkaian kegiatan yang didesain dengan baik untuk mencapai tujuan pendidikan tertentu ${ }^{12}$.

Dua hal yang perlu discermati dalam pengertian di atas. Pertama, strategi pembelajaran merupakan rancangan kegiatan (rangkaian kegiatan) pembelajaran meliputi penggunaan metode, model pembelajaran dan pemanfaatan berbagai sumber daya atau kekuatan dalam proses pembelajaran. Penyusunan strategi baru sampai pada proses penyusunan rencana kerja belum sampai pada kegiatan ataupun tindakan. Kedua, strategi dirancang untuk mencapai tujuan pembelajaran, artinya; alur dari seluruh keputusan penyusunan strategi adalah pencapaian tujuan. Dengan itu, rangkaian langkah-langkah pembelajaran, pemanfaatan berbagai fasilitas, media belajar dan sumber belajar semuanya upaya pencapaian tujuan pembelajaran. Oleh sebab itu, sebelum menentukan strategi, perlu dirumuskan tujuan yang jelas yang dapat diukur keberhasilannya.

\footnotetext{
${ }^{10}$ Kuswarno Engkus, Metodelogi Penelitian Komunikasi, Fenomenologi, Konsepsi Dan Pedoman, Bandung: Widya Padjadjaran, 2009.

${ }^{11}$ Lexy J Moleong, Metodologi Penelitian Kualitatif, Remaja Karya (Bandung, 1989).

12 Khaerul Anam, 'Penerapan Strategi Pembelajaran Inkuiri Untuk Peningkatan Hasil

Pembelajaran IPS Bagi Peserta Didik', 2012, 14-25.
} 


\section{Pengertian Strategi Pembelajaran Inkuiri}

Secara terminologi, inkuiri berasal dari bahasa inggris yakni inquiry yang berarti pertanyaan, pemeriksaan, atau penyelidikan ${ }^{13}$. Inkuiri juga bisa bermakna pemeriksaan dengan sistem interview ${ }^{14}$. Yang berarti strategi pembelajaran inkuiri merupakan strategi pembelajaran yang melakukan pendalaman pemahaman materi melalui pemeriksaan dengan sistem interview. Sedangkan secara epistimologi, Strategi pembelajaran inkuiri dapat diartikan sebagai rangkaian kegiatan pembelajaran yang menitik beratkan pada proses berpikir secara kritis dan analitis untuk mencari, menemukan dan memecahkan sendiri jawaban dari suatu masalah yang dipertanyakan. Proses berpikir biasanya dilakukan melalui interaksi antar guru dan siswa $^{15}$.Strategi pembelajaran inkuiri juga sering disebut dengan strategi heuristic.

Model-Model Pembelajaran Inofatif yang mengarah pada konstruktifistik mengatakan bahwa stategi pembelajar inkuiri merupakan suatu rancangan aktifitas belajar yang mengikutsertakan secara maksimal seluruh kemampuan pesrta didik untuk mencari dan memahami secara sistematis, kritis, logis, dan analisis sehingga mereka mampu merumuskan sendiri temuannya dengan mantap ${ }^{16}$.

Manusia menginterprestasi pengetahuannya dengan banyak hal salah satunya yakni melalui interaksi dengan pengalaman, fenomena,objek, dan lingkungan. Suatu pengetahuan dianggap benar apabila pengetahuan itu mampu menghadapi dan memecahkan persoalan atau fenomena yang sesuai ${ }^{17}$.

Strategi pembelajaran inkuiri (SPI) adalah salah satu dari beberapa strategi yang dalam sistematika penerapannya lebih mengedepankan kepada paham konstrutivisme, yang mana dalam paham ini menganggap bahwa pengetahuan adalah hasil dari konstruksi (bentukan) manusia itu sendiri ${ }^{18}$.

Strategi pembelajaran inkuiri menuntut peserta didikuntuk aktif dalam pembelajaran, hal tersebut merupakan prinsip dalam kurikulum 2013 dimana pola

\footnotetext{
${ }^{13}$ M Pd Trianto, Mendesain Model Pembelajaran Inovatif-Progresif, Jakarta: Kencana, 2009.

${ }^{14}$ A Partanto, Pius, Dan M. Dahlan Al Barry, Kamus Ilmiah Populer, 2001.

${ }^{15}$ Maman Rakhmana Mohamad Agus, Sriyono, 'Penerapan Strategi Pembelajaran Inkuiri Untuk Meningkatkan Hasil Belajar Siswa', 4.1 (2017), 74-82.

${ }^{16}$ Lahadisi, 'INKUIRI : SEBUAH STRATEGI MENUJU PEMBELAJARAN BERMAKNA', 7 (2014), 85-98.

${ }^{17}$ Euis Nurhidayati, 'PEDAGOGI KONSTRUKTIVISME DALAM PRAKSIS PENDIDIKAN INDONESIA', 1.1 (2017), 1-14.

${ }^{18}$ Ahmad Nizar Rangkuti, 'KONSTRUKTIVISME DAN PEMBELAJARAN MATEMATIKA', 2.2 (2014), 61-76.
} 
pembelajaran tidak lagi berpusat kepada guru melainkan kepada siswa itu sendiri. Strategi pembelajaran inkuiri menitikberatkan kepada proses mencari dan menemukan ${ }^{19}$. Dimana dalam strategi pembelajaran ini materi yang diajarkan tidak diberikan secara langsung oleh guru melainkan hal itu menjadi peranan siswa dalam mencari, memahami dan menemukan sendiri materi pelajaran yang di maksud; sedangkan guru sebagai fasilitator dan pembibimbing siswa untuk belajar.

\section{Konsep Dasar SPI}

Pada dasarnya semua metode, model, dan strategi dalam pembelajaran yang ada dalam K-13 sudah menerapkan pembelajaran yang orientasinya mengarah pada definisi inkuiri secara global, hanya saja dalam strategi pembelajaran inkuiri (SPI) ini, inkuiri diolah dengan sedemikian rupa hingga membentuk sebuah tatanan yang memiliki prosedur dan teori tersendiri. Mendefinisikan pendidikan berbasis inkuiri, sama dengan mendefinisikan pendekatan pendidikan multi dimensi. Terdapat banyak inteprestasi visi John Dewey, seperti teori konstruktivisme, pendekatan pemecahan masalah, pembelajaran berbasis proyek, dan sebagainya. Inti dari inkuiri adalah proses pembelajaran yang berpusat pada siswa. Apa yang ingin siswa ketahui,pelajari, dan lakukan merupakan dasar utama dalam pembelajaran berbasis inkuiri ${ }^{20}$.

Dalam perspektif konstruktivisme, pengetahuan tidak bisa ditransfer begitu saja dari seseorang kepada seseorang yang lain, melainkan harus di interpretasikan sendiri oleh tiap-tiap peeseorangan. Tiap orang harus mampu mengkonstruksi pengetahuannya sendiri, karena dalam konstruktivisme pengetahuan dianggap sebagai sebuah proses yang terus berkembang bukan sesuatu yang sudah instan tersaji.

Adapun ciri utama dari SPI. Pertama, strategi pembelajaran inkuiri mengutamakankeaktifan siswa secara maksimal untuk mencari sebuah permasalahan dan menemukan jalan keluarnya. Oemar Hamalik menyatakan bahwa pembelajaran berlandaskan inkuiri adalah sebuah pembelajaranyang menjadikan siswa sebagai pusat pembelajarannya (student-Centered-Strategi) ${ }^{21}$. Artinya, dalam strategi pembelajaran

\footnotetext{
${ }^{19}$ Wina Sanjaya, Strategi Pembelajaran Berorientasi Standar Proses Pendidikan. Jakarta: PT Kencana Prenada Media Group (Cet, 2010).

${ }^{20}$ Ida Damayanti and Mintohari, 'Penerapan Model Pembelajaran Inkuiri Untuk Meningkatkan Hasil Belajar Mata Pelajaran IPA Sekolah Dasar', Jurnal Pendidikan, 2014, 1-12.

${ }^{21}$ Damayanti and Mintohari.
} 
inkuiri siswa tidak lagi dijadikan sebagai objek yang hanya menerima materi pembelajaran dari guru secara verbal, akan tetapi dijadikan sebagai subjek atau pelaku aktif untuk menemukan sendiri inti dari materi dalamproses pembelajaran tersebut.

Kedua, seluruh aktivitas yang dilaksanakan oleh siswa di arahkan untuk mencari dan menemukan sendiri jawaban dari sesuatu yang dipertanyakan/dipermasalahkan, sehingga strategi pembelajaran inkuiri diharapkan mampu meningkatkan kepercayaan diri (self belief) yang dimiliki siswa tersebut.

Ketiga, perlu di ingat bahwa salah satu tujuan dari strategi pembelajaran inkuiri yakni mengembangkan kemampuan berpikir siswa secara sistematis,logis, dan kritis untuk mencapai penguasaan materi yang mendalam dan dapat mengembangkan kemampuan intelektual yang dimiliki oleh siswa secara optimal. Dengan demikian, dalam strategi pembelajaran inkuiri siswa tidak hanya dituntut untuk bisa menguasi materi pembelajaran saja, akan tetapi lebih kepada bagaimana para siswa mampu memaksimalkan potensi yang dimilikinya agar dapat mengembangkan pengetahuannya tentang inti dari sebuah materi pembelajaran. Siswa yang hanya mampu menguasai materi pembelajaran belum tentu dapat mengembangkan kemempuan berfikirnya secara optimal. Sebaliknya, siswa akan mampu mengembangkan kemampuan berfikirnya jika mereka mampu menguasi materi pembelajaran.

\section{Prinsip - prinsip SPI}

Dalam sistematika penerapannya, strategi pembelajaran inkuiri mempunyai beberapa prinsip yang harus diketahui dan dipahami oleh setiap guru yang menerapkannya yakni ${ }^{22}$;

1. Prinsip pengembangan intelektual

Prinsip SPI berorientasi pada pengembangan intelektual siswa, artinya strategi pembelajaran ini tidak hanya melihat hasil belajar yang didapatkan oleh siswa melainkan lebih menitik beratkan kepada proses belajar yang dilakukan siswa untuk mendapatkan hasil tersebut.

\footnotetext{
${ }^{22}$ Lahadisi.
} 
2. Prinsip interaksi

Pada hakikatnya proses pembelajaran adalah proses berinteraksi, baik interaksi antar siswa, interaks siswa dengan guru, atau interaksi siswa dengan sumber belajar lainnya yang berarti tidak menempatkan guru sebagai satusatunya sumber belajar tapi lebih kepada pembimbing interaksi itu sendiri.

3. Prinsip bertanya

Dalam SPI guru juga berperan sebagai penanya, sebab pada dasarnya kemampuan siswa dalam menjawab pertanyaan guru sudah termasuk bagian dari proses berfikir, karenanya kemampuan guru untuk bertanya dalam SPI sangatlah penting.

4. Prinsip belajaruntuk berfikir

Belajar adalah proses berfikir, artinya dalam strategi pembelajaran inkuiri guru juga dituntut untuk mampu memaksimalkan penggunaan otak siswa dalam berfikirketika proses pembelajaran berlangsung.

5. Prinsip keterbukaan

Belajar adalah suatu proses untuk mencari dan menemukan berbagai kemungkinan-kemungkinan yang ada. Oleh sebabtu dalam SPI guru harus memberikan ruang kepada siswa untuk menemukan hipotesis dan memberikan kebebasan dalam mengembangkan hipotesisnya serta secara terbuka untuk membuktikan hipotesisnya tersebut.

\section{Langkah - langkah Pelaksanaan SPI}

Adapun langkah-langkah dalam pelaksanaan model pembelajaran inkuiri adalah sebagai berikut ${ }^{23}$ :

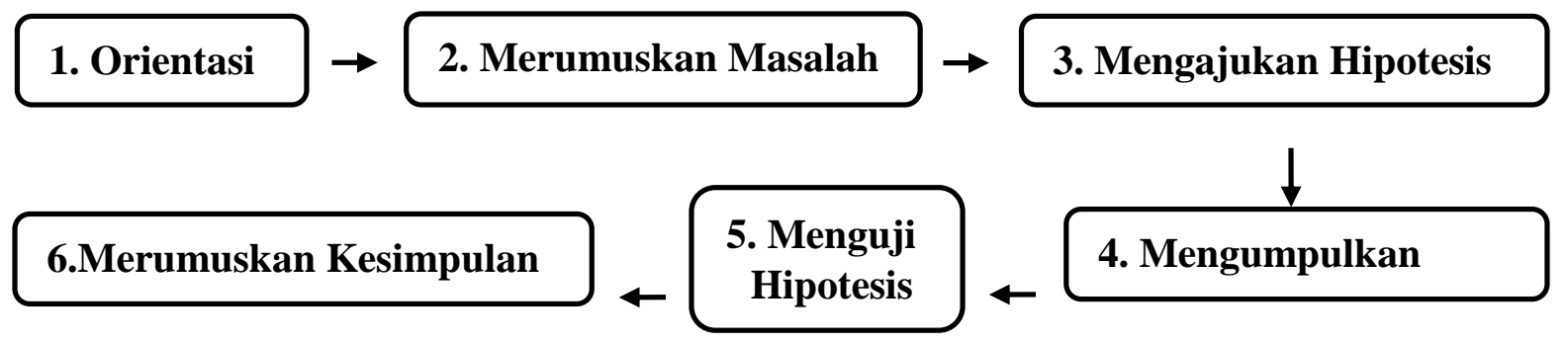

\footnotetext{
${ }^{23}$ Siti Nuraeni, Zahra Azizah Anisah, and Lizda T R I Wahyuni, 'Belajar Dan Pembelajaran', 2015, $1-21$.
} 
1. Orientasi

Pada langkah ini guru mengajak siswa untuk berfikir dalam menyelesaikan suatu permasalahan dengan mengajak dan merangsang siswa dengan sesuatu yang membuatnya tertarik dan termotivasi dalam meari dan menyelesaikan permasalahan tersebut. Langkah ini adalah langkah yang paling penting dalam SPI mengingat keberhasilan SPI bergantung kepada kesadaran siswa untuk mau mecari dan menyelesaikan permasalahan yang tengah dihadapi.

2. Merumuskan masalah

Pada tahapan selanjutnya, guru membawa siswa terhadap persoalanpersoalan yang mengandung unsur teka-teki, hal ini diharapakan dapat menimbulkan tantangan kepada siswa sehingga dapat termotivasi untuk menyelesaikan permasalahan yang dihadapi.

3. Mengajukan hipotesis

Kemampuan atau potensi berfikir setiap individu sebenarnya sudah ada sejak lahir, hal ini dimulai dengan kemampuan individu untuk menebak atau mengira-ngira (berhipotesis) pada sebuah permasalahan. Agar dapat mengembangkan kemampuan berfikir siswa untuk menghasilkan sebuah hipotesis guru hendaknya memberikan beberapa pertanyaanyang dapat membuatsiswa dapat meraba-raba kepada tujuan pembelajaran tersebut sehingga mempermudah siswa untuk bisa berhipotesis sesuai nalar dan kemampuannya dalam berfiikir. Hal ini juga bagus untuk mengembangkan pola berfikir siswa dalam melaksanakan proses pembelajaran.

4. Mengumpulkan data

Langkah ini merupakan salah satu bentuk upaya untuk mengembangkan intelektual siswa melalui proses mental sehingga diharapkan dapat memaksimalkan kemampuannya dalam proses berfikir. Dalam tahapan ini guru memberikan pertanyaan-pertanyaan kepada siswa yang dapat mengarahkan mereka terhadap tujuan pembelajaran yang dimaksud.

5. Menguji hipotesis

Menguji hipotesisadalah prosesuntuk menentukan tingkat kebenaran terhadapdugaan jawaban yang telah idberikan oleh siswa. Dalam menguji 
hipotesis yang terpenting adalah melihat tingkat keyakinan siswa kepada jawaban yang telah ia dapatkan.

6. Merumuskan kesimpulan

Langkah yang terakhir yakni mengajak siswa untuk mampu mendeskripsikan seluruh hasil temuannya yang berlandaskan kepada hasil dari pengujian hipotesisnya secara ringkas.

\section{Hasil Wawancara Informan 1}

Informan pertama yang diwawancarai oleh peneliti yakni bapak Sayyid Muhhamad, informan adalah seorang tenaga pengajar/guru yang sampai saat ini masih aktif berkiprah di lembaga pendidikan formal yang menjadi tempat/objek penelitian kami, tepatnya di SMKN 02 Kraksaan. Informan termasuk salah satu dari beberapa guru di SMKN 02 Kraksaan yang menerapkan Strategi Pembelajaran Inkuiri di dalam pembelajarannya. Maka dari itu peneliti berharap informan dapat menjabarkan lebih dalam lagi mengenai hal-hal yang berkaitan dengan Strategi Pembelajaran Inkuiri dengan mengacu kepada realita yang terjadi di lapangan.

Dari hasil wawancara yang telah kami lakukan, informan menuturkan bahwa sudah banyak guru di SMKN 02 Kraksaan yang telah menerapkan strategi pembelajaran inkuiri terutama dalam mata pelajaran produktif, informan sendiri merupakan guru mata pelajaran PAI di SMKN 02 Kraksaan yang dalam pembelajarannya sering menggunakan strategi pembelajaran inkuiri seperti yang sudah peneliti sebutkan di atas.

Ketika ditanya alasan mengapa informan sering menggunakan SPI, informan menjawab bahwa SPI merupakan strategi yang sangat bagus untuk melatih dan menguatkan memori peserta didik terutama dalam materi pelajaran, SPI juga merupakan strategi yang sangat ideal untuk diterapkan kepada peserta didik mengingat dalam SPI siswa dituntut untuk aktif supaya bisa menyelesaikan permasalahan yang ada dalam materi pelajaran tersebut secara mandiri dalam artian siswa tidak lagi bertumpu kepada guru untuk memahami inti dari pelajaran tersebut, hal itu secara tidak langsung akan mengajak peserta didik untuk menambah pengalaman belajarnya dan akan memperluas pengetahuannya tentang apa yang 
sedang ia pelajari dalam mata pelajaran tersebut. Informanpun mengatakan bahwa strategi ini bisa mengangkat rata-rata nilai hasil UAS siswa hingga 15 angka diatas nilai standar KKM, dengan catatan siswa benar-benar mau berusaha dalam menyelesaikan permasalahan yang ada dalam materi pembelajaran. Akan tetapi informan tidak memandang sebelah mata terhadap strategi pembelajaran yang lain, terbukti ketika wawancara informan juga mengatakan bahwa dalam menentukan strategi yang akan dipakai di dalam kelas seorang guru tentunya juga harus melihat situasi dan kondisi siswa juga sarana pendukung yang ada disekolah tersebut. "Libat kondisi dulu baru piliblah strategi yang pas untuk mereka", tutur informan.

Terkait langkah penerapan strategi pembelajaran inkuiri yang diterapkan oleh bapak sayyid muhammad dalam pembelajarannya yakni;

1. Mengelompokkan siswa.

Siswa dikelompokkan sebanyak materi yang dibutuhkan, minimal 3 kelompok.

2. Siswa mencari sebuah permasalahan.

Contoh : mencari problematika yang ada dalam hubungan pernikahan.

3. Siswa mencari solusi dari permasalahan tersebut.

Siswa mencari jawaban permasalahan melalui berbagai sumber belajar.

4. Beberapa siswa perwakilan kelompok mempresentasikan tugasnya.

Perwakilan kelompok maju untuk mejelaskan hasil dari jawaban permasalahannya.

Berbicara mengenai kendala-kendala yang informan temui ketika menerapkan SPI dalam pembelajarannya, informan mengatakan bahwa masih banyak siswa yang kurang respon terhadap instruksi-instruksi yang informan berikan dikarenakan kurangnya sumber belajar, faktor lingkungan dan asal sekolah juga menjadi keluhan dari informan terkait kurangnya respon siswa dalam pembelajarannya. Kedua, informan mengeluhkan bahwa ketika menerapkan SPI masih banyak siswa yang kurang fokus terhadap apa yang mereka cari, alhasil halitu akan menimbulkan kerancuan pemahamannya terhadap materi pelajaran lebih-lebih ketika mempresentasikan hal yang sudah mereka cari. 
Dimana ada masalah disitu pasti ada solusi, begitu juga yang telah dilakukan oleh bapak sayyid, informan terus berusaha mencari solusi dari setiap masalahmasalah yang informan temui ketika berada di dalam kelas, salah satunya yakni memaksa siswa untuk prsentasi dengan menjadikan presentasi tersebut sebagai tugas individu dan melakukan penegasan dalam segi penilaian, hal ini diharapkan mampu memacu semangat peserta didik untuk menyelasaikan tugas yang mereka peroleh. Informan juga berusaha memadukan strategi pembelajaran inkuiri dengan strategi pembelajaran lain yang dirasa pas untuk diterapkan terhadap siswa tersebut.

\section{Hasil Wawancara dari Informan 2}

Berlanjut kepada informan yang selanjutnya, kami juga berkesempatan mewawancarai seorang guru SMKN 02 Kraksaan yang lain yakni bapak Rahmad Hidayatullah yang tak lain merupakan alumni SMKN 02 Kraksaan yang sekaligus menjadi guru di lembaga tersebut saat ini. Informan adalah guru mata pelajaran produktif di SMKN 02 Kraksaan yang juga sering menerapkan strategi pembelajaran inkuiri ke dalam pembelajarannya sama seperti bapak sayyid muhammad yang menjadi informan pertama peneliti.

Pertama, peneliti menanyakan bagaimana pandangan informan tentang strategi pembelajaran inkuiri terutama yang berada di lembaganya. Informan berpendapat bahwa sebenarnya srategi pembelajaran inkuiri sangat cocok untuk di terapkan di semua lembaga SMK karena menurut informan strategi pembelajaran inkuiri ini dapat menghasilkan sebuah produk yang bisa di wiirausahakan. Hal ini tentu sejalan dengan motto yaang diusung oleh seluruh lembaga SMK yang ada di indonesia yakni "SMK BISA". Strategi ini juga dinilai sebagai strategi yang sangat tepat untuk di terapkan kepada siswa-siswa yang bermalas-malasan selama proses pembelajaran karena dalam strategi pembelajaran inkuiri siswa dituntut untuk aktif dan inovatif selama proses pembelajaran berlangsung.

Selanjutnya peneliti menanyakan bagaimana-bagaimana cara informan dalam menerapkan strategi pembelajaran inkuiri di dalam kelas. Informan pun memaparkan langkah-langkah yang informan lakukan ketika menerapkan strategi pembelajaran inkuiri, yaitu;

1. Guru memberikan sebuah permasalahan 
2. Guru merefleksikan permasalahn yang sudah diberikan guna memancing reaksi dari para siswa

3. Siswa mencari solusi dari permasalahan tersebut

4. Siswa mempresentasikan solusi yang sudah ia temukan secara invidu

5. Mengadakan diskusi ringan setelah presentasi

Kemudian peneliti melanjutkan dengan menanyakan apa kekurangan dari strategi pembelajaran inkuiri yang ada di SMKN 02 Kraksaan. Informan menuturkan bahwa setiap sesuatu pasti ada kelebihan dan kekurangannya tak terkecuali strategi pembelajaran inkuiri, di satu sisi strategi ini sangat bagus untuk meningkatkan keaktifan siswa di dalam kelas, akan tapi di sisi lain strategi ini juga dapat mengakibatkan siswa yang memiliki kecerdasan di bawah rata-rata menjadi semakin malas untuk belajar karena merasa kalah bersaing dengan teman-temannya yang lain.

\section{Hasil Wawancara dari Informan 3}

Informan kami yang selanjutnya yakni beberapa siswa SMKN 02 Kraksaan; antara lain yaitu Sirojul Munir (kelas X TKR 2), Ade Dwi Rifangga (kelas X TKR 2), Putri Lingga Samudra (kelas X TB 1), Naimatul Jannah (kelas XI TB 1), dan Rusydi Hafidz Alinata (kelas XII RPL 1) yang diharapkan oleh peneliti mampu memberikan informasi seputar Strategi pembelajaran inkuiri yang berada di sekolahnya.

Hal pertama yang menjadi pertanyaan peneliti yakni mengenai pengalaman belajar mereka rasakan ketika guru yang mengajar di kelas mereka menerapkan strategi pembelajaran inkuiri, tentunya jawaban yang diterima peneliti sangatlah beragam. Dimulai dari sirojul munir yang mengatakan bahwa ketika gurunya menerapkan strategi pembelajaran inkuiri dirinya merasa menjadi lebih aktif di kelas sekalipun dirinya masih sering merasakan kebingungan ketika menyelasaikan permasalahan yang dia temui dalam pembelajaran. Selanjutnya, putri lingga samudra menyatakan bahwa dirinya merasa lebih bisa memahami materi pembelajaran ketika gurunya menerapkan strategi pembelajaran inkuiri di dalam proses pembelajarannya.

Selanjutnya, peneliti menanyakan kendala-kendala apa saja yang mereka temui dan rasakan dalam memahami materi pembelajaran ketika gurunya menerapkan strategi pembelajaran inkuiri di dalam kelas. Naimatul jannah mengeluhkan bahwa 
dirinya sering mengalami kesulitan dalam menyelesaikan dan memahami tugas yang telah diberikan oleh gurunya karena ia merasa gurunya kurang mempedulikan dan kurang memberinya bantuan ketika ia kebingungan dalam memecahkan suatu permasalahan. Ade dwi rifangga, salah satu siswa yang juga menjadi informan kami secara jujur dan terbuka mengakui bahwa dirinya sangat kebingungan ketika gurunya menerapkan strategi inkuiri di dalam kelas, dirinya mengaku sangat kesulitan apabila harus menyelesaikan sendiri suatu permasalahan yang diberikan oleh gurunya, ia pun menyatakan lebih suka apabila gurunya saja yang menjelaskan karena menurutnya hal tersebut dinilai tidak rumit dan lebih mudah untuk bisa dipahami.

Kemudian peneliti menanyakan hal apa yang biasa dilakukan oleh gurunya saat mereka mengalami kesulitan dalam memahami materi pembelajan ketika guru tersebut menerapkan strategi pembelajaran inkuiri di dalam kelas. Semua informankompak memberikan jawaban yang sama yakni biasanya gurunya memberikan motivasi agar mereka bisa semangat dalam menyelesaikan tugas yang telah diberikan oleh gurunya

\section{PEMBAHASAN}

Untuk dapat memaksimalkan hasil pembelajaran yang diperoleh oleh siswa/peserta didik, guru/pendidik dituntut untuk terus mampu memberikan inovasi-inovasi dalam setiap pembelajarannya, termasuk mampu berinovasi dalam mengembangkan metode,model, dan strategi yang guru terapkan di dalam kelas untuk meningkatkan semangat belajar siswa dan menghindari kebosanan siswa ketika proses pembelajaran berlangsung serta dapat meningkatkan tingkat keberhasilan belajar siswa.

Sudah menjadi hal umum ketika banyak siswa yang menyukai sebuah mata pelajaran karena gurunya mampu memberikan rasa nyaman baginya dalam mata pelajaran tersebut, sebaliknya, juga masih banyak siswa yang awalnya menyukai mata pelajaran tersebut namun karena gurunya tidak mampu menghadirkan rasa nyaman dalam pembelajarannya akhirnya siswa tersebut merasa bosan bahkan ada kemungkinan siswa tersebut akan kehilangan semangat belajarnya. Hal ini tentu akan menjadi faktor penghambat bagi peserta didik untuk terus bisa mengembangkan intelektual dan pengetahuannya akan segala hal, seiring berkembangnya kurikulum 
yang ada di harapkan guru bisa meminimalisir kemungkinan tersebut salah satunya dengan memilih strategi, metode, dan model pembelajaraan yang pas bagi perserta didiknya.

Penerapan strategi dalam sebuah proses pembelajaran bersifat fleksibel. Artinya dalam proses pembelajaran seorang guru tidak hanya bisa menerapkan satu strategi pembelajaran saja melainkan bisa menerapkan strategi pembelajaran lainnya tergantung dengan kebutuhan siswa dalam kelas tersebut dengan melihat kondisi siswa dan sarana pendukung yang ada di sekolah. Pemilihan serta penerapan strategi pembelajaran yang sesuai dengan kebutuhan siswa tentunya akan meningkatkan tingkat keberhasilan belajar siswa tersebut.

Semakin lama zaman semakin maju begitupun dalam dunia pendidikan, inovasi-inovasi baru terus bermunculan terkait metode, model, serta strategi dalam sebuh pembelajaran. Hal ini tak lain bertujuan untuk memaksimalkan efektifitas peran pendidikan dalam mengembangkan semua aspek yang dimiliki oleh peserta didik baik dalam segi kognitif, afektif, dan psikomotorik. Seiring berjalannya waktu beberapa metode, model, dan strategi dalam pembelajaran mengalami perkembangan salah satu strategi yang mengalami perkembangan tersebut yakni strategi pembelajaran inkuiri.

Strategi pembelajaran inkuiri pada hakikatnya merupakan cabang dari strategi pembelajaran aktif atau yang biasa kita dengar dengan istilah active learning, hal ini sesuai dengan definisi active learning yang menyatakan bahwa pembelajaran aktif merupakan strategi pembelajaran yang lebih banyak melibatkan peserta didik dalam proses pembelajaran ${ }^{24}$. Definisi tersebut tak jauh berbeda dengan definisi strategi pembelajaran inkuiri yang menyatakan bahwa strategi pembelajaran inkuiri adalah sebuah strategi yang menuntut siswa mampu berfikir secara sistematis, kritis, dan analisis untuk mencari dan menemukan sendiri jawaban dari suatu permasalahan yang di hadapi ${ }^{25}$. Kedua definisi tersebut sama-sama menekankan kepada aspek keaktifan siswa dalam proses pembelajaran serta menuntut siswa untuk belajar mandiri dalam

\footnotetext{
${ }^{24}$ Hasan Baharun, 'Penerapan Pembelajaran Active Learning Untuk Meningkatkan Hasil Belajar Siswa Di Madrasah', Jurnal Pendidikan Pedagogik, Vol. 1, No.1 (2013), 34-46 <https://doi.org/10.15642/jpai.2017.5.2.224-243>.

${ }^{25}$ Lahadisi.
} 
proses pembelajaran untuk menghindari ketergantungan kepada guru dalam hal memahami materi pembelajaran.

Strategi pembelajaran inkuiri juga memiliki kesamaan dengan contextual teaching and learning atau yang biasa kita sebut dengan istilah CTL yang sama-sama melibatkan komponen pembelajaran efektif kedalam metodologi penerapannya, beberapa komponen pembelajaran efektif yang sama-sama ada dalam strategi pembelajaran inkuri serta CTL yakni konstruktivisme (constructivism), refleksi (reflection), dan menemukan (inquiry) $)^{26}$. Konstruktivisme adalah suatu filsafat yang menganggap pengetahuanadalah hasil dari konstruksi (bentukan) manusia sendiri ${ }^{27}$. Refleksi (reflection) adalah cara berfikir tentang sesuatu yang telah dilakukan di masa lalu. Tujuan dari kegiatan refleksi ini adalah untuk melihat sudah sejauh mana siswa mampu mengembangkan pengetahuan yang di dapat dari pengalaman-pengalaman belajarnya di masa lalu ${ }^{28}$. Sedangkan inkuiri (inquiry) adalah serangkaian aktifitas pembelajaran yang menitik beratkankepada proses berpikir secara kritis dan analitis untuk bisa mencari dan menemukan sendiri jawaban dari suatu permasalahan yang dipertanyakan ${ }^{29}$.

Dengan melihat kesamaan-kesamaan yang ada bukanlah sebuah kemustahilan untuk mengkolaborasikan strategi pembelajaran yang satu dengan strategi pembelajaran yang lain dengan tujuan untuk meminimalisir sesuatu yang tidak di inginkan dalam proses pembelajaran, termasuk mengkolaborasikan strategi pembelajaran inkuiri dengan strategi pembelajaran yang lain bahkan memadukan strategi pembelajaran inkuiri dengan metode yang ada dalam strategi pembelajaran yang lain. Dalam salah satu metode pembelajaran terdapat sebuah metode yang bernama metode pembelajaran kolaboratif yang dapat didefinisikan sebagaifilsafat pembelajaran yang memudahkan para siswa untuk bekerjasama, saling membina,

\footnotetext{
${ }^{26}$ Muhammad Idrus, Hasibuan, 'Model Pembelajaran Ctl (Contextual Teaching and Learning)', Logaritma, II.1 (2014), 1-12.

27 Jeane Santi, 'Penerapan Pendekatan Konstruktivisme Untuk Meningkatkan Hasil Belajar Siswa Pada Pokok Bahasan Tumbuhan Hijau Di Kelas V SDN 3 Tolitoli', 4.3 (2007), 57-71.

${ }^{28} \mathrm{M}$ Arief Fauzan Bukhori, 'Pembelajaran Berbasis Inkuiri Untuk Optimalisasi Pemahaman', $4.1 \& 2$ (2012), 11-21.

${ }^{29}$ Mohamad Agus, Sriyono.
} 
belajar dan berubah bersama, serta maju bersama pula ${ }^{30}$. Namun bukan ini yang dimaksud peneliti dalam hal pengkolaborasian strategi atau metode akan tetapi lebih kepada memadukan antara satu strategi atau metode pembelajaran dengan strategi atau metode pembelajaran yang lain.

Salah satu bentuk kolaborasi strategi atau metode pembelajaran yang peneliti temui yakni kolaborasi antara strategi pembelajaran inkuiri dengan cooperative learning dan kolaborasi antara strategi pembelajaran inkuiri dengan contextual teaching and learning. Pengkolaborasian strategi atau metode dalam pembelajaran ini lahir karena berbedanya sifat dan kecenderungan setiap siswa yang di ajar, menyikapi hal tersebut guru harus melakukan inovasi-inovasi agar terhindar dari berkurangnya semangat belajar siswa salah satunya dengan memadukan atau mengkolaborasikan strategi atau metode yang dipakai. Hal ini menjadi terobosan baru yang diharapkan mampu memaksimalkan hasil belajar siswa dalam memahami materi pembelajaran.

Kolaborasi strategi atau metode yang ada dalam sebuah proses pembelajaran juga berfungsi untuk menutupi bahkan menyempurnakan kekurangan-kekurangan yang ada dalam suatu strategi atau metode pembelajaran guna memaksimalkan fungsi dari strategi atau metode pembelajaran tersebut. Dari hasil pembahasan kami dapat ditarik sebuah kesimpulan bahwa pengkolaborasian strategi atau metode pembelajaran merupakan cara jitu untuk memaksimalkan hasil belajar siswa. Hal ini telah dibuktikan oleh informan 1 dan informan 2 yang telah memadukan SPI dengan berbagai macam strategi atau metode pembelajaran yang lain seperti CTL dan cooperative learning.

\section{KESIMPULAN}

Memaksimalkan hasil belajar siswa adalah tugas dari seorang guru, berbagai hal dan upaya harus dilakukan oleh seorang guru agar dapat menghasilkan hasil belajar yang maksimal salah satunya menerapkan strategi atau metode pembelajaran dalam proses pembelajarannya.

\footnotetext{
${ }^{30}$ Nunuk Suryani, 'Implementasi Model Pembelajaran Kolaboratif Untuk Meningkatkan Ketrampilan Sosial Siswa', Journal of Social Sciences, 2008, 1-23 <https://eprints.uns.ac.id/14000/1/1323-2965-1-SM.pdf>.
} 
Penerapan sebuah strategi atau metode dalam suatu proses pembelajaran bersifat fleksibel yang artinya guru bebas menerapkan strategi atau metode pembelajaran apapun di dalamkelas selama strategi atau metode pembelajaran tersebut dirasa pas dan cocok untuk meningkatkan dan memaksimalkan hasil belajar dari siswa. Dalam sistematika penerapannya, guru juga dapat memadukan atau mengkolaborasikan suatu strategi atau metode pembelajaran dengan strategi atau metode pembelajaran yang lain dengan tujuan untuk mengefektifkan strategi atau metode pembelajaran yang tersebut.

Salah satu bentuk kolaborasi strategi atau metode pembelajaran yang peneliti temui yakni kolaborasi antara strategi pembelajaran inkuiri dengan cooperative learning dan kolaborasi antara strategi pembelajaran inkuiri dengan contextal teaching and learning. Kolaborasi strategi atau metode yang ada dalam sebuah proses pembelajaran juga berfungsi untuk menutupi bahkan menyempurnakan kekurangan-kekurangan yang ada dalam suatu strategi atau metode pembelajaran guna memaksimalkan fungsi dari strategi atau metode pembelajaran tersebut.

\section{DAFTAR PUSTAKA}

Anam, Khaerul, 'Penerapan Strategi Pembelajaran Inkuiri Untuk Peningkatan Hasil Pembelajaran IPS Bagi Peserta Didik', 2012, 14-25

Baharun, Hasan, 'Penerapan Pembelajaran Active Learning Untuk Meningkatkan Hasil Belajar Siswa Di Madrasah', Jurnal Pendidikan Pedagogik, Vol. 1, No (2013), 34-46 <https://doi.org/10.15642/jpai.2017.5.2.224-243>

Buhungo, Ruwiah Abdullah, 'IMPLEMENTASI DAN PENGEMBANGAN KURIKULUM 2013 PADA MADRASAH ALIYAH', Jurnal Manajemen Pendidikan Islam, 3 (2015), 105-13

Bukhori, M Arief Fauzan, 'Pembelajaran Berbasis Inkuiri Untuk Optimalisasi Pemahaman', 4 (2012), 11-21

Damayanti, Ida, and Mintohari, 'Penerapan Model Pembelajaran Inkuiri Untuk Meningkatkan Hasil Belajar Mata Pelajaran IPA Sekolah Dasar', Jurnal Pendidikan, 2014, 1-12

Elfida, Yeni, 'Penggunaan Metode Inkuiri Untuk Meningkatkan Hasil Belajar IPS Siswa Di Kelas IV SDN 27 Batang Anai Kabupaten Padang Pariaman', 1 (2017), 55-61

Engkus, Kuswarno, Metodelogi Penelitian Komunikasi, Fenomenologi, Konsepsi Dan Pedoman, Bandung: Widya Padjadjaran, 2009

Idrus, Hasibuan, Muhammad, 'Model Pembelajaran Ctl (Contextual Teaching and Learning)', Logaritma, II (2014), 1-12 
Jannah, Fathul, 'Pendidikan Islam Dalam Sistem Pendidikan Nasional', Dinamika Ilmu, 13 (2013), 161-73

Lahadisi, 'INKUIRI : SEBUAH STRATEGI MENUJU PEMBELAJARAN BERMAKNA', 7 (2014), 85-98

Lely, 'Peningkatan Hasil Belajar Matematika Melalui Metode Inkuiri Di Kelas IV SDN 13 IV Koto Aur Malintang Kabupaten Padang Pariaman', 1 (2017), 23-30

Mohamad Agus, Sriyono, Maman Rakhmana, 'Penerapan Strategi Pembelajaran Inkuiri Untuk Meningkatkan Hasil Belajar Siswa', 4 (2017), 74-82

Moleong, Lexy J, Metodologi Penelitian Kualitatif, Remaja Karya (Bandung, 1989)

Murni Eva Marlina, 'Kurikulum 2013 Yang Berkarakter', Jurnal JUPIIS 2085-482X, Vol 5 (2013), 27-38

Nizar Rangkuti, Ahmad, 'KONSTRUKTIVISME DAN PEMBELAJARAN MATEMATIKA', 2 (2014), 61-76

Nuraeni, Siti, Zahra Azizah Anisah, and Lizda T R I Wahyuni, 'Belajar Dan Pembelajaran', 2015, 1-21

Nurhidayati, Euis, 'PEDAGOGI KONSTRUKTIVISME DALAM PRAKSIS PENDIDIKAN INDONESIA', 1 (2017), 1-14

Nurwati, Tri, 'Peningkatan Aktivitas Dan Hasil Belajar Mata Diklat Produktif Pemasaran Dengan Menggunakan Metode Inkuiri Pada Siswa Kelas XI Pemasaran SMK Negeri 02 Purworejo Semester Genap Tahun 2010/2011', 2011, 193-205

Partanto, A, Pius, Dan M. Dablan Al Barry, Kamus Ilmiah Populer, 2001

Sanjaya, Wina, Strategi Pembelajaran Berorientasi Standar Proses Pendidikan. Jakarta: PT Kencana Prenada Media Group (Cet, 2010)

Santi, Jeane, 'Penerapan Pendekatan Konstruktivisme Untuk Meningkatkan Hasil Belajar Siswa Pada Pokok Bahasan Tumbuhan Hijau Di Kelas V SDN 3 Tolitoli', 4 (2007), 57-71

Shoimin, Aris, 68 Model Pembelajaran Inovatif Dalam Kurikulum 2013 (Yogyakarta: Arruzz media, 2017)

Suryani, Nunuk, 'Implementasi Model Pembelajaran Kolaboratif Untuk Meningkatkan Ketrampilan Sosial Siswa', Journal of Social Sciences, 2008, 1-23 $<$ https:/ / eprints.uns.ac.id/14000/1/1323-2965-1-SM.pdf>

Tafsir, Ahmad, Filsafat Pendidikan Islam,(interaksi Jasmani, Rohani, Kalbu Memanusiakan Manusia), Remaja Rosda Karya, Bandung.[Google Scholar], 2006

Trianto, M Pd, Mendesain Model Pembelajaran Inovatif-Progresif, Jakarta: Kencana, 2009

Uno, Hamzah B, Model Pembelajaran Menciptakan Proses Belajar Mengajar Yang Kreatif Dan Efektif, Jakarta: Bumi Aksara, 2009 